\title{
Elevated acute-phase protein in stunted Nepali children reporting low morbidity: different rural and urban profiles
}

\author{
C. Panter-Brick ${ }^{1}$, P. G. Lunn ${ }^{2}$, R. Baker ${ }^{3}$ and A. Todd ${ }^{1}$ \\ ${ }^{1}$ Department of Anthropology, University of Durham, Durham DHI 3HN, UK \\ ${ }^{2}$ Department of Biological Anthropology, University of Cambridge, Cambridge, UK \\ ${ }^{3}$ Department of Social Anthropology, University of Edinburgh, Edinburgh, UK
}

(Received 5 April 2000 - Revised 28 July 2000 - Accepted 22 August 2000)

\begin{abstract}
This study examined the associations between severity of stunting, plasma protein concentrations and morbidity of 104 Nepali boys, aged 10-14 years, living in contrasting environments. Boys from a remote village were compared with three similarly aged urban groups: poor squatters, homeless street children, and middle-class schoolchildren. All but the middle-class group were stunted, particularly village boys whose mean height-for-age z-score $(-2 \cdot 97$, SD $0 \cdot 82$ ) indicates severe growth retardation. Stunting was significantly associated with increased plasma levels of the acute-phase protein $\alpha_{1}$-antichymotrypsin itself inversely related to plasma levels of albumin. Plasma ACT levels of village children (mean $1.52 \mathrm{~g} / \mathrm{l}$, SD 0.43) were three to four times higher than those of squatters and homeless street children, and five times higher than those of middle-class boys. Despite being the most severely stunted and having the most abnormal plasma protein values, village children reported the lowest burden of disease, a contradiction which may reflect exposure to sub-clinical infections or habituation to illness and low expectation of treatment. This study draws attention to the strikingly high levels of ACT and of stunting in the rural sample, and cautions on the use of uncorroborated morbidity reports across different epidemiological and socio-ecological environments. Possible mechanisms to explain the impact of illness and inflammation on growth faltering are discussed.
\end{abstract}

Child growth: Growth failure: Nutritional status: Acute-phase proteins

Malnutrition and growth faltering of children remain major health concerns in most developing countries. It is, however, becoming increasingly clear that although compromised food quality and availability can explain much of the poor growth of children in some areas, in others, for example in rural Gambia, infection and disease appear to be the more important variables (Lunn, 2000). Such studies suggest that it is essential that disease prevalence and its impact on growth be assessed as part of any investigation into the aetiology of malnutrition.

A wide battery of indicators are available to evaluate health and nutritional status of populations in the developing world. Cross-sectional health interviews are routinely undertaken with a view to establish major causes of morbidity or usage of health facilities despite widespread concern regarding survey methodologies and the usefulness of morbidity reports (Ross \& Vaughan, 1986). However, even sub-clinical illness can affect growth and more recently, a great deal of interest has developed in measuring acute-phase proteins in non-clinical settings to detect the presence and severity of systemic inflammation as a reflection of the immune response to infection (Rousham et al. 1998). $\alpha_{1}$-antichymotrypsin (ACT), in particular, has a number of advantages over other acute-phase proteins: it is very sensitive to a wide range of infections, and unlike $\mathrm{C}$ reactive protein (another effective marker of inflammation) it remains elevated for a longer time period (Calvin et al. 1988; Thompson et al. 1992).

Few studies have examined the relationship between acute-phase proteins and morbidity reports (Rousham et al. 1998), or even clinical examinations and morbidity histories (Katz et al. 1998). Such studies emphasise that while morbidity surveys have important practical advantages over detailed clinical or biochemical surveys - in terms of cost, time, personnel and sample size - their value depends upon the extent to which reported data reflect the

\footnotetext{
Abbreviations: ACT, $\alpha_{1}$-antichymotrypsin; ALB, albumin; CWIN, Child Workers in Nepal; HAz, height-for-age z-score; WAz, weight-for-age zscore; $\mathrm{WHz}$, weight-for-height $\mathrm{z}$ score.

* Corresponding author: Dr C. Panter-Brick, fax + 44 (0) 191 3742870, email Catherine.Panter-Brick@durham.ac.uk
} 
actual health status of the individuals concerned. Their data examine the internal validity of morbidity reports within a population. Thus Rousham et al. (1998) corroborated maternal reports of child illness with examination of the biochemical and immunological status of rural Bangladeshi children, using plasma ACT, albumin (ALB), and tests of intestinal permeability. Plasma ACT concentrations showed highly significant associations with morbidity, particularly with fever, the combination of fever and respiratory infections, and diarrhoea. The study demonstrated both the usefulness of ACT as a marker of clinical or sub-clinical infections and the agreement between biochemical measures and morbidity reports in a population from a developing country.

High ACT levels have also been associated with poor growth in a relatively small number of studies undertaken in the developing world. In rural Gambia, elevated ACT values were related to the poor weight gain of infants between 2 and 8 months of age (Lunn et al.1999). Among pre-adolescent children in Nepal, ACT values were both positively related to reports of acute infections and negatively associated with growth increments (Parkin \& Lunn, 1998).

In this study, we examined associations between plasma concentrations of ACT and ALB, growth status and morbidity in Nepali boys living in contrasting geographical and socio-economic environments. Our focus was to compare health profiles across markedly different ecological settings, rather than test the internal validity of morbidity reports within a particular group. We proceed by reporting on plasma levels of ACT and albumin, and severity of stunting, then comment on apparent differences in morbidity profiles.

\section{Methods}

Four populations of Nepali boys ( $n$ 104) - villagers, urban squatters, homeless street children, and middle-class pupils - participated in measures of growth status, morbidity, and biochemical markers of infection (during NovemberDecember 1993). This project was part of a multidisciplinary study of a larger sample of rural and urban Nepali children (Baker et al. 1996; Panter-Brick et al. $1996 a$ ) which extended to measures of physical activity via heart rates (Panter-Brick et al. 1996b,c), of psychosocial arousal via salivary cortisol (Panter-Brick et al. 1996d, Panter-Brick \& Pollard, 1999), of demography and lifestyles (Baker et al. 1997), together with ethnographic observation (Baker, 1998). One social anthropologist, one biological anthropologist, and one medical doctor collaborated in the fieldwork. Issues of consent and participation were carefully considered (Baker et al. 1996).

\section{Study groups}

The populations have been described extensively in PanterBrick et al. (1996a). The village boys lived in a remote rural area (without roads, electricity, or provision of sanitation) in the foothills of the Himalaya $(1870 \mathrm{~m})$ in central Nepal. They were routinely involved in subsistence activities and also attended the village school. The urban groups were all located in Kathmandu (1300 m). Squatter boys lived in poor, overcrowded and illegal settlements; their parents were mostly road-sweepers, market vendors or jewellery-makers and had migrated from rural areas in the last 15 years. Most boys worked on the streets, and some attended a school run by a nearby non-governmental organisation, Child Workers in Nepal (CWIN). Homeless boys were street children who lived independently from their families, spending their nights on the streets or sheltering with CWIN. They subsisted principally from begging and picking scrap metals and plastics from household and municipal dumps, for resale to junkyards. By contrast, middle-class pupils, drawn from a private feepaying school, were from a privileged background.

All available 6-14-year-olds were initially recruited for growth measurements ( $n 307$ boys) and demographic inquiry (n 329 boys), achieving a representative sample of the homeless (23\% of the known homeless child population) and a total sample of available boys for other groups (Panter-Brick et al. 1996a; Baker et al. 1997). The study concentrated on boys as there were very few homeless street girls. The purposes of the study were explained to the children by assistants who were known to them. The project was facilitated by the village leaders, CWIN, school teachers, and the long-standing links of two of the authors with the village, homeless, and school communities.

\section{Measures}

Anthropometric status was taken by a single investigator following standard procedures (Weiner \& Lourie, 1981). Height, weight (with minimal clothing), mid-upper arm circumference and skinfolds were measured using portable field equipment (a Harpenden anthropometer, a Salter electronic scale with $0.2 \mathrm{~kg}$ precision, tape and calipers). Age reports from the children were corroborated with actual demographic records for village and schoolchildren, and with staff from a non-governmental organisation for street and squatter children. Nepali children knew their exact age with reference (in months and years) to the Hindu or Tibetan calendar (ages had to be approximated for a few of the homeless children).

Blood spots were taken by fingerprick with an autolancet device (Autolet II, Baxter Scientific Products, McGraw Park, IL, USA). Five drops (about $100 \mu \mathrm{l}$ ) of blood were spotted on pre-printed circles on standardised filter paper (Schlecher and Schull \#903, Keene, NH, USA). Samples were dried at room temperature and refrigerated for no longer than a week before shipment to the UK where they were kept at $-20^{\circ} \mathrm{C}$ until assay.

For the ACT and ALB assays, $9 \mathrm{~mm}$ diameter discs were punched out of the blood spots and the proteins eluted by incubation in isotonic phosphosaline buffer $(250 \mu \mathrm{l}$, $0.05 \mathrm{M}, \mathrm{pH} 7.4$ ) for $48 \mathrm{~h}$ at $4^{\circ} \mathrm{C}$. (No further protein was eluted during a second $48 \mathrm{~h}$ incubation). Using data supplied by Schlecher and Schull, the $9 \mathrm{~mm}$ filter discs were calculated to contain material from $12.5 \mu$ l of whole blood, thus the concentration of material in the incubation fluid was equivalent to a 1:20 dilution of the blood. ACT concentration in the incubation fluid was measured by an 
automated immunoturbidimetric technique (Calvin \& Price, 1986) using antibodies (Cat. No. Q0367) and standards (Cat. No. X0908) supplied by Dako, (Ely, Cambridge, UK). ALB was measured in a similar way using Q0328 antibody and the same standard preparation.

Plasma concentrations were estimated from whole blood values using a multiplication factor of $2 \cdot 26$. This value was determined experimentally in a separate series of measurements in which blood values, obtained as described, were regressed against plasma concentrations determined by standard procedures from the same blood samples (PanterBrick et al. 1996d). It should be recognised that these plasma concentrations are only approximate, calculated for comparative purposes rather than for determining absolute values. A similar method for comparing blood spot and plasma values has been developed for C-reactive protein (McDade et al. 2000).

Morbidity was evaluated from the reports of children, who were asked whether or not they were ill and what were their complaints. Two sets of morbidity data were considered: first, reports of health versus ill-health on the actual days on which children gave a blood sample (during the last two weeks of fieldwork); second, pooled information from a separate $10 \mathrm{~d}$ period (at the beginning of fieldwork) during which children were measured for growth and cortisol. The competency with which children evaluated ill-health was also demonstrated using childfocused participatory research methods (Baker et al. 1996).

\section{Statistical analysis}

To standardise anthropometric variables, height-for-age (HAz), weight-for-age (WAz) and weight-for-height (WHz) z-scores were calculated from children's heights and weights relative to the US National Center for Health Statistics, using the Centers for Disease Control Anthropometric Software Package (CASP 3.1). The technical error of measurement indicated good reliability for initial height and weight measurements (Panter-Brick et al. $1996 a)$.

Disease burden was calculated by a simple count of the frequency of different illnesses reported by children. Only 74 reports were made on the actual blood sampling days (when each child was seen on a single day). However, a total 1198 reports of health/ill-health were made at the time of the growth and cortisol survey (when each child was seen on an average ten occasions).

Differences between the four groups of children in terms of growth status and biochemical markers were evaluated with analyses of variance and post hoc multiple range tests, accepting $P<0.05$ as significance level. The relationship of plasma protein markers with growth status was examined by multiple regression. The same results pertained whether or not age was included in the regression models (to correct for the potential problem of using the National Center for Health Statistics reference population to express the growth profile of Nepali children).

\section{Results}

Sample characteristics are shown in Table 1. All groups of children, except for schoolboys, were stunted ( $\mathrm{HAz}<-2$ ) but not wasted ( $\mathrm{WHz}$ close to zero). The $\mathrm{z}$-scores for villagers indicate severe stunting ( $\mathrm{HAz}$ close to -3 ) and growth profiles that were significantly different from urban groups $(P<0.002$ for $\mathrm{HAz}, P<0.05$ for $\mathrm{WHz}$ and $P<$ 0.06 for $\mathrm{WAz}$ ).

Plasma ALB concentrations were normally distributed. Plasma ACT values were normally distributed within urban groups (mean 0.39 , SD $0 \cdot 15$; median 0.37 , range $0.18-$ $0.88 \mathrm{~g} / \mathrm{l}$ ), but the high values of villagers (mean 1.53 , SD 0.42 ; median 1.50 , range $0.72-2.67 \mathrm{~g} / \mathrm{l}$ ) skewed the overall distribution. Relative to urban groups, villagers showed very high plasma ACT $(P<0.0001$, Fig. 1) and lower ALB $(P<0.001)$ levels. Within urban groups, the homeless showed higher ACT concentrations than both squatters $(P<0.001)$ and middle-class children $(P<0.0001)$, with values for squatters also higher $(P<0.025)$ than the middle-class children. Plasma ALB levels were also different between the homeless and middle-class children $(P<0.029)$.

Thus, village boys showed both severe stunting and high ACT values, while the urban middle-class boys showed least stunting and the lowest ACT values; the poor squatter and homeless boys showed intermediary values. Plasma concentrations of ACT and ALB were strongly and negatively correlated $(r-0.385, P<0.0001$ for all samples). ACT showed a significant relationship with both stunting and wasting $(\mathrm{HAz}$ and $\mathrm{WHz}, P<0.002$ and $P<0.01$ respectively; Table 2 ). The relationship with $\mathrm{HAz}$

Table 1. Characteristics of sample children

(Values are means and their standard deviations)

\begin{tabular}{|c|c|c|c|c|c|c|c|c|c|c|}
\hline & \multicolumn{2}{|c|}{ Village } & \multicolumn{2}{|c|}{ Squatter } & \multicolumn{2}{|c|}{ Homeless } & \multicolumn{2}{|c|}{ Middle class } & \multicolumn{2}{|c|}{ All } \\
\hline & Mean & SD & Mean & SD & Mean & SD & Mean & SD & Mean & SD \\
\hline$n$ & 30 & & 20 & & 24 & & 30 & & 104 & \\
\hline Age & 11.63 & $1 \cdot 16$ & 11.54 & 1.05 & 12.25 & 0.85 & 12.03 & 0.76 & 11.86 & $0.99^{*}$ \\
\hline \multicolumn{11}{|c|}{ Growth status (NCHS z-scores) } \\
\hline $\mathrm{HAz}$ & -2.97 & 0.82 & -2.45 & 0.92 & -2.83 & 0.65 & -1.75 & 0.83 & -2.53 & $0.93^{\star \star \star \star}$ \\
\hline WAz & -2.06 & 0.50 & -2.07 & 0.52 & -1.89 & 0.57 & -1.49 & 0.66 & -1.89 & $0 \cdot 60^{\star \star \star \star}$ \\
\hline $\mathrm{WHz}$ & 0.13 & 0.54 & -0.53 & 0.74 & 0.29 & 0.57 & -0.27 & 0.68 & -0.07 & $0.70^{\star \star}$ \\
\hline \multicolumn{11}{|c|}{ Plasma markers } \\
\hline ACT $(g / l)$ & 1.52 & 0.43 & 0.37 & 0.11 & 0.53 & 0.17 & 0.31 & 0.09 & 0.73 & $0.58^{\star \star \star \star}$ \\
\hline ALB $(g / l)$ & $29 \cdot 12$ & 6.33 & 32.56 & $4 \cdot 74$ & 31.82 & $5 \cdot 20$ & 34.80 & 4.33 & $32 \cdot 04$ & $5 \cdot 61^{\star * *}$ \\
\hline
\end{tabular}

Significant differences between groups: ${ }^{\star} P<0.05,{ }^{\star \star} P<0.01,{ }^{\star \star \star} P<0.001,{ }^{\star \star \star \star} P<0.0001$, from analyses of variance between four groups of children. 


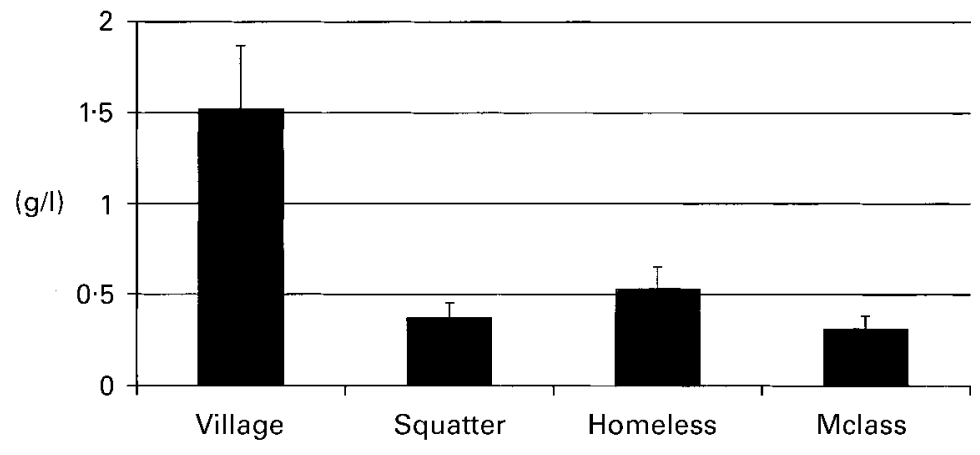

Fig. 1. ACT levels in rural and urban Nepali children.

held true for urban groups (stunted boys showed higher ACT, $P<0.029$ ), but was not marked for the villagers.

On the days of blood spot collection, villagers reported symptoms of ill-health on half as many days as did the squatters or homeless children (7\% versus $15 \%$ and $13 \%$ respectively; $n$ as in Table 1$)$. There are no comparable morbidity data for the middle-class boys, because they could not be interviewed at length at the time, being engaged in class revision. Comparison of squatter and homeless children who reported ill versus healthy revealed no apparent differences in ACT levels; however, larger sample sizes would be required to evaluate the significance of the small differences noted (i.e. $n 98$ for a mean difference of $0.04 \mathrm{~g} / \mathrm{l}$ between 'ill' and 'healthy' squatter children, after the formula in Mascie-Taylor, 1994). In the case of villagers, there were only $2 \mathrm{~d}$ of reported illness (for which ACT was $2 \mathrm{~g} / \mathrm{l}$, compared to $1.5 \mathrm{~g} / \mathrm{l}$ on the remaining $28 \mathrm{~d})$. With these data, the association of morbidity and ACT within groups cannot be tested.

The relative profiles for morbidity reports across the four study groups were also examined from the more extensive data (a total of 1198 reports) obtained during the growth survey. Again, the difference between rural and urban groups was striking. Villagers reported the lowest disease burden $(13 \%)$; their reports were predominantly intestinal (including worms) and diarrhoeal complaints. Within urban groups, as expected, middle-class pupils reported ill on relatively fewer days $(45 \%)$ than did squatter and homeless boys (60\% and $71 \%$ respectively).

\section{Discussion}

The most striking results of this study concern the ACT profiles of rural Nepali children relative to urban counterparts. The values for village boys (mean $1.52 \mathrm{~g} / \mathrm{l}$, SD 0.42 ) are three to four times the levels observed in squatter or homeless children (who are urban destitutes, commonly collecting refuse on the streets), and five times the levels of middle-class schoolchildren. Values for urban groups (mean $0.39 \mathrm{~g} / \mathrm{l}$, SD 0.15 ) are within the normal range reported by Calvin et al. (1988) for UK adults (0.33$0.64 \mathrm{~g} / \mathrm{l})$. However, the values for Nepali rural children are well above those hitherto reported for populations in nonclinical settings (although few studies have been undertaken). Rousham et al. (1998), for example, found that ACT values for 'healthy' rural Bangladeshi children, 2-5 years old, averaged $0.54 \mathrm{~g} / \mathrm{l}$ (no SD given). In the Gambia, values for 22 children, 6-36 months old, with persistent diarrhoea and severe protein and energy malnutrition, averaged $0.9(\mathrm{SD} 0.2) \mathrm{g} / \mathrm{l}$, with a range $0.65-1.37 \mathrm{~g} / \mathrm{l}$ (Sullivan et al. 1991).

Values for ACT are sensitive to the actual assay used in the laboratory as well as dependent on the actual conversion of blood spot values to plasma equivalent. In addition, they may be sensitive to collection procedures in the field (there was a $2 \mathrm{~d}$ delay in refrigerating rural samples, incurred for their transport by foot to Kathmandu; however such delay is unlikely to have elevated village ACT values). While these variables might affect the

Table 2. Relationship between biochemical markers and growth status (Data are statistics obtained by ANOVA)

\begin{tabular}{|c|c|c|c|c|c|c|c|c|c|c|}
\hline & \multicolumn{5}{|c|}{ All samples } & \multicolumn{5}{|c|}{ Three urban samples* } \\
\hline & $r^{2}$ & Variable & Coefficient & SE & Significance & $r^{2}$ & Variable & Coefficient & SE & Significance \\
\hline$\overline{\mathrm{HAz}}$ & $0 \cdot 10$ & $\begin{array}{c}\text { Intercept } \\
\text { ACT } \\
\text { ALB }\end{array}$ & $\begin{array}{l}-1.765 \\
-0.539 \\
-0.001\end{array}$ & $\begin{array}{l}0.633 \\
0.170 \\
0.018\end{array}$ & $\begin{array}{l}0.006 \\
0.002 \\
0.525\end{array}$ & 0.08 & $\begin{array}{c}\text { Intercept } \\
\text { ACT } \\
\text { ALB }\end{array}$ & $\begin{array}{r}-1.900 \\
-1.608 \\
0.001\end{array}$ & $\begin{array}{l}0.845 \\
0.721 \\
0.023\end{array}$ & $\begin{array}{l}0.028 \\
0.029 \\
0.780\end{array}$ \\
\hline $\mathrm{WHz}$ & 0.07 & $\begin{array}{c}\text { Intercept } \\
\text { ACT } \\
\text { ALB }\end{array}$ & $\begin{array}{r}-0.750 \\
0.343 \\
0.001\end{array}$ & $\begin{array}{l}0.484 \\
0.130 \\
0.014\end{array}$ & $\begin{array}{l}0.125 \\
0.010 \\
0.331\end{array}$ & 0.04 & $\begin{array}{c}\text { Intercept } \\
\text { ACT } \\
\text { ALB }\end{array}$ & $\begin{array}{r}-0.679 \\
0.969 \\
0.000\end{array}$ & $\begin{array}{l}0.699 \\
0.596 \\
0.019\end{array}$ & $\begin{array}{l}0.336 \\
0.109 \\
0.848\end{array}$ \\
\hline
\end{tabular}

\footnotetext{
* Excluding villagers on the basis of their significantly different ACT and ALB profiles.
} 
absolute values presented in this study, they are unlikely to affect the relative profile of rural and urban groups.

Together with elevated ACT, village children show hypoalbuminaemia (mean ALB $29.0 \mathrm{~g} / 1$ (SD 6.3; range 1447) compared to $33.2 \mathrm{~g} / \mathrm{l}$ (SD 4.9; range 22-46) in urban groups). By comparison, Sullivan et al. (1991) report a normal range of albumin levels of $35-45 \mathrm{~g} / \mathrm{l}$ (population unspecified) and values for young Gambian children with protein-energy malnutrition averaging $34.1 \mathrm{~g} / \mathrm{l}$ (SD 7.2; range $20 \cdot 7-45 \cdot 5)$. The inverse relationship found between plasma ACT and ALB suggests that the observed variation in both proteins results from the presence of an acute phase response to infection/inflammation in the children. During an acute phase reaction, plasma levels of ACT and other acute-phase proteins become elevated, whilst ALB values are lowered. The markedly high ACT and low ALB seen in the village boys indicate a particularly high level of infection/inflammation in this group.

The rural Nepali boys also show severe stunting (heightfor-age is close to -3 standard deviations away from the National Center for Health Statistics median). In earlier publications, such high levels of stunting have been linked to the combination of a very monotonous diet (poor in animal fat and protein) and high levels of physical activity (Panter-Brick et al. 1996a,c). However it is noteworthy that the village in question did not experience significant food shortages; it was self-sufficient in cultivated foods within an agro-pastoral economy (the results of a year-long food intake study are found in Koppert, 1988). The present study therefore suggests that much of the stunting in these children is a consequence of acute and chronic infections resulting in inflammatory responses, as indexed by ACT. The negative relationship between $\mathrm{HAz}$ and ACT was demonstrated in urban groups, although it was not marked among villagers (perhaps because the profile of this smaller sample was characterised by already very high levels of stunting and ACT).

What light can be shed on the high levels of stunting and ACT observed in the village sample? Ten years previously, fieldwork in the same village showed (for a sample of $0-$ 49-month-olds, including all the boys involved in this study), that moderate to severe stunting was evident after the first year of life and also that child morbidity - reported by mothers during structured interviews - had a significant impact on growth velocity over 9 months of observation (Panter-Brick, 1997). Moreover, parasite infestation was common (79\% Ascaris, $57 \%$ Ancylostoma duodenale, $36 \%$ Trichuris trichuria and $31 \%$ Entamoeba histolytica) in the general population (analyses of ninety-six stool samples, reported in Panter-Brick, 1997). Vitamin A intakes were only $53 \%$ of recommended daily allowances for 7-15-year-old children (Koppert, 1988). Haemoglobin values, measured by a battery-operated miniphotometer, averaged 12.0 (SD 2.8) g/dl for adult men (reported in Panter-Brick et al. 1992). It is not known whether parasite infestation could explain the elevated ACT values as no data on pathogens were collected in this study. However, the previously observed high levels of parasitic infestation, some of which require faeco-oral transmission, suggest an environment poor in overall hygiene, with frequent exposure to a range of pathogens. Under such conditions both clinical and sub-clinical infections and infestations may be expected and it seems likely that this situation is reflected in the elevated ACT values (see Rousham et al. 1998). There may also be some synergistic relationships with nutritional status (vitamin A has been linked to acutephase protein responses to infection; Filteau et al. 1995). There was no known malaria, AIDS, or tuberculosis (save one case of an adult village migrant), which might explain elevated ACT.

Another tentative explanation for the high ACT values observed in this study can be offered in light of the important links between infection, growth faltering and damaged gut function summarised in Lunn (2000). In the Gambia, levels of ACT (together with C-reactive protein, cortisol, and immunoglobulins $\operatorname{IgA}, \operatorname{IgG}$ and $\operatorname{IgM}$ ) were found to be elevated early in life and to be closely related to growth faltering. Measures of intestinal permeability also revealed early and significant damage to the mucosa of the small intestine (Lunn et al. 1991). Small bowel mucosal enteropathy results both in a loss of enzymes (required for food digestion and absorption) and in a leaky intestinal barrier (enabling translocation of macromolecules and subsequent triggering of local and systemic immune and inflammatory mechanisms). Lunn (2000) argued that mucosal damage and the persistence of chronic inflammation were likely to account for poor growth and that abnormal intestinal permeability values persisted throughout childhood and adulthood. Moreover, the prevalence of mucosal enteropathy was very high (it was found in every one of over 400 rural Gambian infants studied). The condition was for the most part asymptomatic - it was present in apparently healthy Gambian infants and did not relate to diarrhoea prevalence. As there is now evidence that similar mucosal damage occurs in children from other parts of the developing world (Lunn, 2000), it seems possible that the Nepali boys showing a similar cluster of biochemical variables (low ALB, high ACT) accompanying poor growth may also have a damaged small intestinal mucosa. To test this possibility, measurements of intestinal permeability have been initiated in the study area.

A final observation concerns the associations between children's reported morbidity and observed levels of acutephase protein. Village boys reported the lowest burden of disease, which contradicted the biochemical evidence for significantly higher ACT levels relative to urban counterparts. By contrast, within the three urban groups, levels of the acute-phase protein broadly reflected levels of reported morbidity. As stated above, it is possible that villagers suffered from gut enteropathy, which would lead to growth stunting even in the absence of obvious signs of infection. However, it is also likely that villagers significantly underreported symptoms of ill-health due to a routine experience of illnesses and a low expectation of health care treatment (a health post had recently been built in the village, but was not staffed). In turn, the fact that homeless boys reported the most ill-health can be attributed both to the likelihood of exposure to trauma and pathogens, related to their lifestyle as street children, and to their expectation of treatment, related to their access to free medical care provided by CWIN. The squatter boys shared both the same day-time environment (begging and shifting garbage on the 
streets) and medical care facilities. The complaints of middle-class boys (stomach-ache, headache) are probably related to a high awareness of health matters rather than to actual significant ill-health.

Morbidity reports, therefore, not only reflect different exposure to diseases, but also different experiences of illnesses or habituation to ill-health as well as different demands or expectations for treatment. As Ross \& Vaughan (1986) noted, it is difficult to assess 'the differential importance attributed to identical symptoms by subgroups of the same population. For example, diarrhoea in young children may be considered 'normal' and not worth reporting...'. The rates of sickness reported by respondents across different regions of the same country are even more likely to vary and to be difficult to interpret (as noted by McDade, 1999). In the present study, morbidity reports and biochemical data were collected across a range of environments contrasting both in terms of pathogen exposure (related to lifestyle and risk factors) and health care expectations (related to socio-economic milieu and uptake of health care). If one took the differences in morbidity reports between rural and urban Nepali boys at face value, one would be tempted to conclude that infectious burdens are unlikely to account for their differences in growth status (Todd et al. 1996). However, the analysis of the biochemical evidence warrants a different conclusion.

This study draws attention to the very high levels of ACT and of stunting in the rural Nepali population. It also concludes that morbidity reports should be evaluated with caution when comparing very different epidemiological and socio-ecological environments; such reports are best corroborated with biochemical measures.

\section{Acknowledgements}

The research was facilitated by Tribhuvan University, Kathmandu, and CWIN.

\section{References}

Baker R (1998) Negotiating identities: A study of the lives of street children in Nepal. PhD dissertation, University of Durham.

Baker R, Panter-Brick C \& Todd A (1996) Methods used in research with children in Nepal. Childhood 3, 171-193.

Baker R, Panter-Brick C \& Todd A (1997) Homeless street boys in Nepal: Their demography and lifestyle. Journal of Comparative Family Studies 28, 129-146.

Calvin J \& Price CP (1986) Measurement of serum $\alpha_{1^{-}}$ antichymotrypsin by immunoturbidemetry. Annals of Clinical Biochemistry 23, 206-209.

Calvin J, Neale G, Fotherby KJ \& Price CP (1988) The relative merits of acute phase proteins in the recognition of inflammatory conditions. Annals of Clinical Biochemistry 25, 60-66.

Filteau SM, Morris SS, Raynes JG, Arthur P, Ross DA, Kirkwood BR, Tomkins AM \& Gyapong JO (1995) Vitamin A supplementation, morbidity, and serum acute-phase proteins in young Ghanaian children. American Journal of Clinical Nutrition 62, 434-438.

Katz J, West KP Jr, LeClerq SC, Thapa MD, Khatry SK, Shresta SR, Pradhan EK \& Pohkrel RP (1998) Agreement between clinical examination and parental morbidity histories for children in Nepal. Journal of Tropical Pediatrics 44, 225229.

Koppert GJA (1988) Alimentation et culture chez les Tamang, les Ghale et les Kami du Nepal. Thèse de 3ème cycle, Faculté de Droit et de Science Politique, Aix-Marseille.

Lunn PG (2000) The impact of infection and nutrition on gut function and growth in childhood. Proceedings of the Nutrition Society 59, 147-154.

Lunn PG, Northrop-Clewes CA \& Downes RM (1991) Intestinal permeability, mucosal injury and growth faltering in Gambian infants. Lancet 338, 907-910.

Lunn PG, Erinoso HO, Northrop-Clewes CA \& Boyce SA (1999) Giardia intestinalis is unlikely to be a major cause of the poor growth of rural Gambian infants. Journal of Nutrition $\mathbf{1 2 9}$, 872-877.

Mascie-Taylor CGN (1994) Statistical issues in anthropometry. In Anthropometry: the individual and the population, pp. 56-77 [SJ Ulijaszek and CGN Mascie-Taylor, editors]. Cambridge: Cambridge University Press.

McDade TW (1999) Culture change, stress, and immune function in Western Samoan youth. PhD dissertation, Emory University.

McDade TW, Stallings JF \& Worthman CM (2000) Culture change and stress in Western Samoan youth: Methodological issues in the cross-cultural study of stress and immune function. American Journal of Human Biology 12, 792-802.

Panter-Brick C (1997) Seasonal growth patterns in rural Nepali children. Annals of Human Biology 24, 1-18.

Panter-Brick C, Miller DG \& Eggerman M (1992) Hemoglobin levels and step test performance of men and women in Nepal. American Journal of Human Biology 4, 481-491.

Panter-Brick C \& Pollard TM (1999) Work and hormonal variation in subsistence and industrial contexts. In Hormones, Health, and Behavior: A Socioecological and Lifespan Perspective, pp. 139-183 [C Panter-Brick and CM Worthman, editors]. Cambridge: Cambridge University Press.

Panter-Brick C, Todd A \& Baker R (1996a) Growth status of homeless Nepali boys: Do they differ from rural and urban controls? Social Science \& Medicine 43, 441-451.

Panter-Brick C, Todd A, Baker R \& Worthman C (1996b) A comparative study of flex heart rate in three populations of Nepali boys. American Journal of Human Biology 8, 653-660.

Panter-Brick C, Todd BA, Baker R \& Worthman C (1996c) Heart rate monitoring of physical activity among village, school and homeless Nepali boys. American Journal of Human Biology $\mathbf{8}$, 661-672.

Panter-Brick C, Worthman CM, Lunn P, Baker R \& Todd A (1996d) Urban-rural and class differences in biological markers of stress among Nepali children. American Journal of Human Biology 8, 126 [abstract].

Parkin N \& Lunn P (1998) Inflammatory response to acute infections is associated with decreased linear growth among Nepali children. Annals of Human Biology 25, 396 [abstract].

Rousham EK, Northrop-Clewes CA \& Lunn PG (1998) Maternal reports of child illness and the biochemical status of the child: the use of morbidity interviews in rural Bangladesh. British Journal of Nutrition 80, 451-456.

Ross DA \& Vaughan JP (1986) Health interview surveys in developing countries: A methodological review. Studies in Family Planning 17, 78-94.

Sullivan PB, Mascie-Taylor CGN, Lunn PG, Northrop-Clewes CA $\&$ Neale G (1991) The treatment of persistent diarrhoea and malnutrition: Long-term effects of in-patient rehabilitation. Acta Paediatrica Scandinavica 60, 1025-1030.

Thompson D, Milford-Ward A \& Whicher JT (1992) The value of acute phase protein measurements in clinical practice. Annals of Clinical Biochemistry 29, 123-131. 
Todd A, Baker R \& Panter-Brick C (1996) Physical growth of homeless boys in Nepal. Journal of the Nepal Medical Association 118\&119, 152-158.
Weiner JS \& Lourie JA (1981) Practical Human Biology. London: Academic Press. 